\title{
De la imagen-transparente a la imagen-opaca. Hacia una taxonomía de la imagen fotográfica a partir de la filosofía de Gilles Deleuze
}

\author{
Alejandro León \\ Pontificia Universidad Católica del Perú
}

Resumen: La obra de Deleuze es ciertamente heteróclita. A lo largo de su vida se ocupó de una variedad de temas sorprendente: historia de la filosofía, psicoanálisis, política, literatura, pintura, cine, entre otros. Sin embargo, un territorio de singular relevancia para la configuración del siglo $\mathrm{XX}$ no fue abordado por el autor de Mil mesetas: la fotografía. Esta ausencia es inquietante, no solo debido a la importancia cultural de la fotografía, sino también porque las reflexiones en torno a la imagen son recurrentes a lo largo de toda su obra. La presente investigación no buscará determinar las razones por las que Deleuze no exploró el ámbito de lo fotográfico, pues creemos que una pregunta como esta es, por decir lo menos, ociosa. Intentaremos, en una dirección diferente, prolongar sus reflexiones con la finalidad de desplegar las intuiciones presentes en su filosofía que nos puedan ayudar a abordar la problemática de lo fotográfico. En este sentido, nuestro objetivo será elaborar una taxonomía de la imagen fotográfica a partir de la distinción de dos tipos fundamentales: la imagentransparente y la imagen-opaca.

Palabras clave: Deleuze, fotografía, tipología, índice, pensamiento.

Abstract: Deleuze's work is certainly heterogeneous. Throughout his life he managed to deal with an amazing variety of subjects: history of philosophy, psychoanalysis, politics, literature, painting, cinema, among others. However, the author of A Thousand Plateaus did not address a particularly relevant area for the twentieth century configuration-photography. This absence is unsettling not only because of the cultural importance of photography, but also because his reflections concerning the concept of image are a recurrent theme throughout his work. This research will not seek to determine the reasons why Deleuze did not explore the field of photography, because we believe that a question like this is, to say the least, idle. On the contrary, we will 
try to prolong his reflections in order to unfold the intuitions found in his philosophy that may help us to address the issue of the photographic. In this sense, our objective will be to develop a taxonomy of the photographic image from the distinction of two main types: the transparent image and the opaque image.

Keywords: Gilles Deleuze, photography, typology, index, thinking.

\section{$\S 1$. Deleuze $y$ la fotografía: una inquietante ausencia}

Uno de los rasgos más destacados de la producción de Deleuze es el carácter heterogéneo de los temas de los que se ocupó. Si recorrió el psicoanálisis, la literatura, la política, el cine, la historia, la lingüística, la pintura y la filosofía fue porque encontró en estos dominios los elementos y las fuerzas necesarias para llevar a cabo un proyecto de mayor alcance: renovar nuestra imagen del pensamiento y permitir, gracias a ello, nuevas posibilidades de existencia'.

Teniendo en mente este proyecto, Deleuze parece haber sido muy consciente de qué autores, problemas y conceptos le serían útiles para construir su propia filosofía. Sin embargo, a pesar de esta "claridad metodológica"2, en palabras de Michael Hardt, no deja de sorprenderme que Deleuze no haya considerado a la fotografía como un objeto de pensamiento digno de ser tomado en cuenta. Son muy pocas las referencias a la fotografía en su obray, cuando aparecen, son marginales e, incluso, despectivas ${ }^{3}$. Esta ausencia se torna aún más inquietante

I Cf. Deleuze, Gilles, Nietzsche y la filosofía, Barcelona: Anagrama, 2002, III, I4, p. 145.

2 Hardt, Michael, Deleuze. Un aprendizaje filosófico, Buenos Aires / Barcelona / México D.F.: Paidós, 1994, p. 31.

3 Cuando Deleuze se refiere a la fotografía, por ejemplo en sus estudios sobre cine o, principalmente, en su famoso libro sobre el pintor Francis Bacon, Lógica de la sensación, la califica como un medio expresivo sometido a los grilletes de la lógica de la representación. Parece ser que Deleuze solamente vio en la fotografía una forma de perpetuar la "imagen dogmática del pensamiento", y no una posible herramienta de liberación del pensamiento, como sí lo eran ciertas formas de cine y pintura. Tal vez esta sea la razón de que no existan muchos estudios sobre la relación entre la filosofía de Gilles Deleuze y la fotografía. Entre los que existen, destacan: el libro editado por Mieke Bleyen, Minor Photography. Connecting Deleuze and Guattari to Photography Theory, New York: Cornell University Press, 2012. Vale la pena mencionar, también, el número 23 de la Revista Rhizome, dedicado a las relaciones entre Gilles Deleuze y la fotografía: http://rhizomes.net/issue23/index.html 
si tenemos en cuenta que la problemática de la imagen -concepto complejo y polisémico ${ }^{4}-$ ocupa un lugar privilegiado y recurrente a lo largo de su obra.

Por ejemplo, en la década de 1980, publicó dos libros monumentales de filosofía a partir de una reflexión sobre la imagen cinematográfica: La imagen-movimiento (1983) y La imagen-tiempo (1985). En estos sostuvo que los grandes cineastas, al igual que los filósofos, piensan, aunque lo hacen con imágenes y no con conceptos $^{5}$. En Proust y los signos (1964), Deleuze propuso una singular teoría del signo orientada a redefinir las nociones de verdad y aprendizaje. Podríamos recordar también el gran libro en torno a la obra pictórica de Francis Bacon: Lógica de la sensación (198I). Fuera del ámbito estético, la problematización del concepto "imagen" ha estado presente en sus dos obras más importantes: en Lógica del sentido (1969), en la discusión con la filosofía platónica en torno a la diferencia entre los "íconos" y los "simulacros"; y en Diferencia y repetición (1968), en la cuestión medular de la imagen dogmática del pensamiento y del pensamiento sin imagen ${ }^{7}$.

Dado el puesto clave que ocupan las imágenes en su filosofía, ¿por qué nunca consideró a la fotografía como un interlocutor legítimo? Mi intriga aumenta si tenemos en cuenta que la fotografía ha sido, como pronosticó Walter Benjamin en los albores del siglo $X X^{8}$, la técnica productora de imágenes más importante de los últimos I50 años, convirtiéndose así en el fundamento de nuestra forma de percibir, sentir y pensar el mundo. Actualmente, para bien o para mal, las imágenes no solo duplican la realidad como creía Platón'; por el contrario, ocupan su lugar y la producen ${ }^{10}$. Y en el origen de este desplazamiento desde las cosas hacia las imágenes, como afirma Vilém Flusser, está el dispositivo

4 Cf. Melot, Michel, Breve historia de la imagen, Madrid: Siruela, 2010, pp. II-20.

5 Cf. Deleuze, Gilles, La imagen-movimiento. Estudios sobre cine I, Barcelona: Paidós, 1984, p. 12.

6 Cf. Deleuze, Gilles, Lógica del sentido, Barcelona: Paidós, 2005, pp. 298-300.

7 Cf. Deleuze, Gilles, Diferencia y repetición, Barcelona: Amorrortu, 2002, pp. 201-255.

8 Cf. Benjamin, Walter, "La obra de arte en la época de su reproductibilidad técnica", en: Discursos interrumpidos I, Madrid: Taurus, 1982, p. 40.

9 Véase el ejemplar pasaje de la República conocido como la "alegoría de la caverna" (cf. Platón, República, Madrid: Alianza Editorial, 2000, pp. 405-4I0).

10 "Là oú le monde réel se change en simples images, les simples images deviennent des êtres réels (...)” (Debord, Guy, La société du spectacle, Paris: Gallimard, 1992, p. 23). 
fotográfico": “(...) las imágenes técnicas omnipresentes han empezado a reestructurar mágicamente la "realidad" en un escenario semejante a una imagen. Lo que esto implica es una especie de olvido. El hombre se olvida de que produce imágenes a fin de encontrar su camino en el mundo; ahora trata de encontrarlo en estas"'2.

Una razón más para inquietarnos por esta ausencia es que la fotografía, durante los años en que Deleuze escribió la mayor parte de su obra, fue tomada como objeto de estudio por investigadores provenientes de diferentes dominios y tradiciones, entre los que destacan Roland Barthes ${ }^{13}$, Susan Sontag ${ }^{14}$, Rosalind Krauss $^{15}$, Pierre Bourdieu ${ }^{16}$ y John Berger ${ }^{17}$. Cabe resaltar, además, que André Bazin, a quien Deleuze menciona repetidas veces en sus estudios sobre cine, escribió en el año 1945 un texto fundamental para la teoría fotográfica del siglo XX: "Ontología de la imagen fotográfica”. Asimismo, en el año 1992 Jacques Derrida ${ }^{18}$ dio una larga entrevista sobre la especificidad del medio fotográfico y sus relaciones con la imagen, la mirada y el referente. Es, pues, por decir lo menos extraño, que Deleuze no se haya interesado por participar en dichos debates, en los que no se veía a la fotografía como una simple técnica o un arte menor sino que, por el contrario, se la consideraba un objeto de pensamiento privilegiado.

Finalmente, vale la pena mencionar que la juventud de Deleuze coincidió con un periodo particularmente fructífero en la "Historia" de la fotografía: aquel que se desarrolló a partir del nacimiento de las grandes agencias documentales,

II Véase el proyecto fotográfico "Sputnik" de Joan Fontcuberta: http://www.fontcuberta. com

I2 Flusser, Vilém, Hacia una filosofía de la fotografía, México D.F.: Editorial Trillas, 1990, p. 13.

I3 Barthes, Roland, La cámara lúcida, Barcelona: Paidós, 2009; “El mensaje fotográfico” (pp. II-28) y "Retórica de la imagen" (pp. 29-48), en: Lo obvio y lo obtuso, Barcelona: Paidós, 2009.

14 Sontag, Susan, Sobre la fotografía, México D.F.: Alfaguara, 2006. Véase, especialmente, los ensayos "En la caverna de Platón" (pp. 13-44) y "El mundo de la imagen" (2I3-252).

I5 Krauss, Rosalind E., Lo fotográfico. Por una teoría de los desplazamientos, Barcelona: Gustavo Gili, 2002.

16 Bourdieu, Pierre, Un arte medio. Ensayos sobre los usos de la fotografía, Barcelona: Gustavo Gili, 2003. Véase, especialmente, las páginas 5I-I72.

17 Berger, John, Modos de ver, Barcelona: Gustavo Gili, 2014.

18 Entrevista a Jacques Derrida, "Copia, firma, archivo", en: Revista Minerva, № 7, 2008 (http://www.revistaminerva.com/articulo.php?id=228). 
entre las que destacó la mítica Magnum ${ }^{19}$, fundada en 1947 por Henri CartierBresson, Robert Capa y David Seymour, entre otros. Asimismo, en plena madurez intelectual, Deleuze vivió un periodo en el que la fotografía, "inquieta consigo sí misma" en palabras de Jean-Claude Lemagny ${ }^{20}$, ingresó a los museos y al mercado del arte, gracias a lo cual finalmente logró obtener el prestigio y el reconocimiento social que había perseguido durante más de 100 años ${ }^{21}$.

Creo, entonces, que tenemos buenas razones para inquietarnos por esta ausencia. No obstante, mi interés no es descubrir por qué Deleuze no tomó a la fotografía como un tema de investigación privilegiado. Me parece, por el contrario, que la mejor forma de ser fiel a Deleuze no es dando círculos al interior de su propia filosofía -lo dicho- sino yendo gracias a ella más allá de ella -lo no dicho-. De esta forma, el objetivo de esta presentación es recurrir a la filosofía de Deleuze para intentar establecer las bases de una posible "historia natural" de la imagen fotográfica. Para ello, me apoyaré en: (i) la metodología de los estudios sobre cine, (ii) la teoría del signo desarrollada en Proust y los signos, (iii) y la definición del ejercicio del pensamiento propuesta en Diferencia y repetición.

\section{§ 2. ¿Qué es la fotografía? De la pregunta por la identidad a la pregunta por los tipos}

¿Qué puede aportar una taxonomía de las imágenes fotográficas al estado actual de las discusiones en torno a este medio? Hoy, con más de 150 años de existencia, lo fotográfico aún está muy lejos de ser una categoría de pensamiento cerrada ${ }^{22}$. Aparece, parafraseando a Kant, como un campo de batalla.

19 http://www.magnumphotos.com

20 Lemagny, Jean-Claude y Rouillé André, Historia de la fotografía, Barcelona: Martínez Roca, 2008, pp. I87-232.

21 Un ensayo muy interesante y completo que describe cómo la fotografía logró ingresar al mundo del arte gracias a su legitimación a través del MOMA es "El tribunal de la fotografía", escrito por Christopher Phillips en 1982 (cf. Picazo, Glòria y Ribalta, Jorge (eds.), Indiferencia y singularidad, Barcelona: Gustavo Gili, 2003).

22 En relación a esto Jan Baetens se pregunta: "Why has it becomes so difficult to think about photography?" (Baetens, Jan, "Conceptual Limitations of Our Reflections on Photography: The Question of 'Interdisciplinarity”', en: Elkins, James (ed.), The Art Seminar. Photography Theory, New York: Routledge, 2007, p. 54. 
Sin embargo, este estado crítico no es gratuito ni azaroso, pues ya desde su llegada oficial al mundo en 1839 la fotografía nació problematizada: se generó un gran debate en torno a su naturaleza: ies arte o ciencia?, imedio de expresión o documento?, índice o ícono?, ificción o realidad? ${ }^{23}$, debate en el que Charles Baudelaire, "guía espiritual" de su tiempo, tuvo una participación destacada al asumir una posición paradójica, ya que, por un lado, despreció a la fotografía al calificarla como simple "sirviente" de las artes y las ciencias; pero, al mismo tiempo, le asignó una serie de usos y funciones sociales que hicieron, paulatinamente, que ocupase un lugar destacado en la cultura del siglo $\mathrm{XIX}{ }^{24}$. Asimismo, viajando un poco más hacia atrás en el tiempo, en el periodo "proto-fotográfico" (1790-1820), en palabras Geoffrey Batchen, ya se podían apreciar con claridad las ambigüedades del medio, expresadas en las dificultades para elegir una denominación, fijar una definición, escoger una técnica y determinar unas funciones. Esto llevó a Batchen a afirmar que en el origen de la fotografía nunca hubo una identidad estable sino, parafraseando a Derrida, pura différance ${ }^{25}$. Parece ser, pues, que esta diferencia originaria ha marcado esencialmente a la fotografía a lo largo de toda su historia. Por ello, hoy tal vez más que nunca, debido al advenimiento de la tecnología digital y al auge de internet, se siguen produciendo acalorados debates en torno a su definición, usos sociales, géneros, valor, vínculos con otras disciplinas, etcétera ${ }^{26}$. Tanto así que algunos críticos, como el español Joan Fontcuberta, han señalado que vivimos en una época "post-fotográfica", lo cual no tiene nada que ver con una posible muerte del medio sino con su radical apertura, multiplicidad y plasticidad, y, por ello, con su constante redefinición: actualmente

23 Cf. Rouillé, André, La photographie. Entre document et art contemporain, París: Gallimard, 2005 , p. 30.

24 Cf. Baudelaire, Charles, "El público moderno y la fotografía" en: Curiosidades estéticas, Madrid: Jucar, 1988, p. 251.

25 "Dondequiera que miremos, los orígenes de la fotografía resultan desplazados por un perturbador juego de diferencias, lo que Derrida ha denominado la economía de la différance" (Batchen, Geoffrey, Arder en deseos. La concepción de la fotografía, Barcelona: Gustavo Gili, 2004, p. 8). Y, más adelante: “Dondequiera que hayamos mirado, los orígenes de la fotografía aparecen inscritos en un juego dinámico de diferencias (el juego de la différance) que rehúsa asentarse en ninguno de los polos de identificación existentes (naturaleza, cultura, las características intrínsecas del medio, las exigencias del contexto)" (ibid., p. 203).

26 Un ejemplo claro de este carácter ambiguo fue la polémica en torno a la serie de fotos ganadora del IVSalón Nacional de la Fotografía ICPNA el año 2014 en Lima: http://www.limagris. com/ganadores-del-4-salon-nacional-de-fotografia-icpna-2014/ 
pareciera que la fotografía difiere tanto de sí que cuando intentamos decir algo significativo (idefinitivo?) acerca de ella, ya está siendo otra $\operatorname{cosa}^{27}$.

Así, pues, teniendo en cuenta el carácter "líquido" y "protéico" de la fotografía -su multiplicidad-, nuestro objetivo es aportar, en medio de este perpetuo campo de batalla, herramientas conceptuales que nos ayuden a pensar las imágenes fotográficas desde su propia inmanencia, es decir, tomando en cuenta su carácter material y plural, para así poder pensarlas fuera de las categorías idealistas y esencialistas establecidas por la historia de la fotografía dominante ${ }^{28}$. Pues esta, al imponer sus códigos-periodos, géneros, escuelas, autores, estilos, etcétera-, impide considerar en las imágenes lo que estas tiene de más íntimo: la organización de los signos que la constituyen. Por ello, creemos que no solo es útil sino también necesario realizar una tipología de las imágenes fotográficas.

Esta taxonomía se impone, al mismo tiempo, pues nos ayuda a dejar atrás la nostalgia metafísica que de cuando en cuando nos empuja a preguntarnos ¿qué es la fotografía? Esta pregunta, como muestra Deleuze en su libro sobre Nietzsche, no es la adecuada para comprender cabalmente un concepto, pues apunta a la determinación de una esencia entendida como un universal abstracto. El inconveniente con esta definición es que destila las diferencias reales en favor de una identidad ideal. Paradójicamente, en este proceso de volatilización el pensamiento pierde aquello que busca pensar, ya que la pregunta por la esencia nunca hace referencia a las fuerzas concretas que hacen que una cosa sea lo que es. Ahí radica su debilidad. Por ello, Deleuze propone que la forma más potente de comprender la naturaleza de un concepto es plantear

27 Se ha escrito y discutido mucho sobre el cambio de paradigma que hemos vivido a raíz del advenimiento de la tecnología digital. Vale la pena resaltar el primer libro que utilizó el término "post-fotografía": The reconfigured eye. Visual truth in the Post-photographic era de W.J. Mitchel (Cambridge: MIT Press, 1992). Poco tiempo después, Lev Manovich escribió un pequeño artículo en el que discutía las ideas de Mitchel sobre la nueva fotografía: "Paradoxes of Digital Photography" (disponible en: http://manovich.net/index.php/projects/paradoxes-of-digitalphotography). Otro autor que ha reflexionado sobre este tema es el español Joan Fontcuberta. Véase, especialmente La cámara de Pandora. La fotografía después de la fotografía (Barcelona: Gustavo Gili, 2013) y El beso de Judas. Fotografía y verdad (Barcelona: Gustavo Gili, 1997).

28 Por ejemplo, la historia de Beaumont Newhall en Historia de la fotografía, Barcelona: Gustavo Gili, 2002. 
preguntas de corte pluralista, ya que estas sirven para dramatizarlo: ¿quién quiere?, ¿para qué?, ¿cuándo? icómo?, ¿dónde?, ¿de qué manera?, etcétera ${ }^{29}$.

\section{$\S 3$. El principio de la taxonomía en los estudios sobre cine: la presentación del tiempo}

Sin embargo, ¿cómo comenzar a pensar esta multiplicidad? Frente a un mundo tan vasto y heterogéneo de imágenes fotográficas, ino será una tarea destinada al fracaso realizar dicha clasificación de signos? ¿No terminaremos elaborando una lista absurda como la de aquella enciclopedia china que menciona Borges en "El idioma analítico de John Wilkins"? En ¿Qué es la filosofía? Deleuze pedía un poco de orden para protegernos del caos, pues “(...) no hay cosa que resulte más dolorosa, más angustiante, que un pensamiento que se escapa de sí mismo, que las ideas que huyen, que desaparecen apenas esbozadas, roídas ya por el olvido o precipitadas en otras ideas que tampoco dominamos"30. Este pedido puede sonar paradójico si recordamos que Deleuze defendió las multiplicidades, los devenires, las líneas de fuga, las desterritorializaciones, los proceso esquizofrénicos, en fin, una compresión de la realidad rizomática ${ }^{31}$; sin embargo, la paradoja se diluye al considerar que para Deleuze el pensamiento nómada -y su aplicación concreta en alguna investigación- también necesita puntos de apoyo, territorios en los cuales asentarse para tomar impulso $y$, como cometas, viajar hacia tierras incógnitas. Por ello, aunque Deleuze rechaza la idea metafísica de fundamento -entendido como un principio absoluto del pensar, un arché-, no creo equivocarme si sostengo que aceptaría la necesidad de hallar una plataforma, contingente y provisional, a partir de la cual comenzar a pensar, pues siempre se piensa desde algún lugar, aunque este sea cualquier lugar: un "entre dos" o intermedio ${ }^{32}$.

Teniendo en cuenta esta necesidad, Deleuze distingue dos tipos básicos de imágenes cinematográficas (la imagen-movimiento y la imagen-tiempo) en función de la forma en que cada una expresa el tiempo y del tipo de realidad

29 Cf. Deleuze, Gilles. Nietzsche y la filosofía, pp. 109-II0.

30 Deleuze, Gilles y Felix Guattari, ¿Qué es la filosofía?, Barcelona: Anagrama, 1993, p. 201.

3I Cf. Deleuze, Gilles y Felix Guattari, Mil mesetas. Capitalismo y esquizofrenia 2, Valencia: Pre-Textos, 2000, pp. 9-32.

32 "La vida del nómada es intermezzo" (ibid., p. 385). 
que plasman en sus representaciones ${ }^{33}$. Este será el criterio elegido por Deleuze para poder desarrollar la taxonomía de la imagen cinematográfica que propone en sus estudios sobre cine.

Por un lado, en el cine construido a partir de la hegemonía de la imagenmovimiento solo podemos acceder a una presentación indirecta del tiempo gracias al recurso técnico del montaje y el plano. Este tipo de imagen, que en términos históricos coincide con el cine clásico, está formada a partir del "esquema sensorio-motriz", caracterizado por presentar las relaciones entre el individuo y su entorno de forma "realista". Deleuze define el realismo del cine clásico a partir de los siguientes rasgos: la clara determinación del medio en el cual los individuos están ubicados; el conocimiento -actual o potencialde la secuencia de acontecimientos que constituyen la trama de la narración; la capacidad de los sujetos involucrados en la historia de reconocer el medio en el que se encuentran y, gracias a ello, reaccionar de forma adecuada ante los eventos que se le presentan. Así, en palabras de Nietzsche, el realismo del cine de la imagen-movimiento surge de un mundo "cualificado verídicamente”. En síntesis, la imagen-movimiento (y sus variedades: imagen-percepción, imagen-afección e imagen-acción) se caracteriza por dos rasgos fundamentales: la presentación indirecta del tiempo y el realismo.

Por otra parte, el cine de la imagen-tiempo surge a partir de la quiebra del esquema sensorio-motriz luego de la Segunda Guerra Mundial. La pérdida de confianza en dicho modelo ( $y$ en la Historia) empujó a los cineastas a producir imágenes que no estuviesen orientadas a organizar sus signos bajo los presupuestos del realismo. Gracias al abandono de esta posición las imágenes se liberaron de su sumisión al movimiento ( $y$ a la acción) y se hizo factible una presentación directa del tiempo. Lo que el cine moderno nos muestra, entonces, es la dislocación de los lazos que mantenían eficazmente unido al hombre con su mundo. A partir de ahora el hombre vagabundea por espacios indeterminados, no es capaz de reconocer el entorno circundante, por tanto, no sabe cómo reaccionar ante los acontecimientos que se le presentan. Se entrega, nos dice Deleuze, inevitablemente, a la aprehensión de situaciones ópticas y sonoras puras. Sin embargo, esta incapacidad para reaccionar ante 
su entorno, no hace del individuo un "vegetal" o un ser "impotente"; por el contrario, el mismo movimiento por el cual la acción se hace imposible activa un movimiento de génesis al interior del individuo: nace el pensamiento. Al verse enfrentado a la imposibilidad de reconocer y actuar, el hombre se ve obligado a mirar, escuchar, en fin, percibir. Estas nuevas percepciones, no sometidas a los imperativos utilitarios y cognitivos, producen afecciones que, a su vez, empujan al pensamiento a pensar lo impensado. Así, gracias a la quiebra del esquema sensorio-motor $y$ a la falla en el reconocimiento el individuo deviene pensador. En síntesis, la imagen-tiempo (y sus variedades) se caracteriza por dos rasgos fundamentales: la presentación directa del tiempo y la crisis del realismo ${ }^{34}$.

Este breve resumen de las que son, a mi juicio, las tesis centrales de los estudios sobre cine nos sirve para enfatizar dos aspectos que haremos nuestros en la presente investigación: por un lado, Deleuze, metodológicamente, asume un punto de partida en su clasificación de imágenes: las relaciones entre tiempo y realidad; por el otro, esta consideración hace que su reflexión sobre la imagen cinematográfica vaya más allá de la semiótica, hacia una ontología (teoría del ser) y una noología (teoría del pensamiento).

Teniendo en cuenta estas consideraciones, ¿cuál podría ser un punto de partida coherente para la construcción de una taxonomía de la imagen fotográfica?

\section{§ 4. La teoría del índice como principio para una posible tipología de la imagen fotográfica}

La fotografía, como toda imagen, nace en y habla del mundo. Sin embargo, su singularidad radica en la particular forma en que teje dicha relación con la realidad: no lo hace -aunque normalmente pensamos lo contrario- a partir de su semejanza con el objeto representado (ícono), tampoco a partir de los significados sociales que puede expresar (símbolo); en otra dirección, lo que define a la relación de la imagen fotográfica con el mundo es su carácter indicial. No son pocos, ni poco importantes, los autores que han señalado que la

34 Cf. Deleuze, Gilles, La imagen-tiempo. Estudios sobre cine 2, Barcelona: Paidós, 1987, pp. $|I-4|$. 
singularidad de la imagen fotográfica radica en ser una huella (producida por contigüidad y causalidad) del referente del que proviene $y$ al que nos reenvía. Dos textos cruciales al respecto, muy diferentes en contenidos, estilos y pretensiones, pero que sin embargo coinciden en su diagnóstico final, son $L a$ cámara lúcida de Roland Barthes (1980) y Lo fotográfico. Por una teoría de los desplazamientos $(1990)^{35}$ de Rosalind Krauss. Para Barthes, lo que define a la fotografía se sintetiza en su famoso "esto ha sido": aquello que observamos en cualquier imagen fotográfica ha, de una u otra manera, existido en algún momento determinado del pasado. Por su parte, Krauss interpreta el devenir del arte a lo largo del siglo XX, como si este estuviese fundado en la categoría de "índice", y ya no como estuvo el arte clásico en la de "ícono" (mímesis). Para Krauss lo fotográfico - lo indicial- ha llegado a ser una categoría de pensamiento que influyó fuera del ámbito de la fotografía, generando un cambio de paradigma en la historia del arte.

Pero Barthes y Krauss no son los únicos que han definido lo fotográfico de esta manera. Existe una tradición indicial muy fuerte que se remonta por lo menos al texto de André Bazín que mencionamos anteriormente-"Ontología de la fotografía”- y que alcanza a autores claves como Philippe Dubois. No obstante, también existen críticos como Fontcuberta, Manovich y Mitchell quienes, desde hace algunos años, defienden la idea de que hoy vivimos, debido al advenimiento de la tecnología digital, en una época "post-fotográfica", en la cual habríamos entrado, por así decirlo, en un periodo de crisis del index.

Más allá de esta polémica, sobre la que habrá que volver, en nuestro análisis partiremos, entonces, de aquel rasgo que parece ser propio de la imagen fotográfica: su relación crítica con la realidad. Más allá de la postura asumida -a favor o en contra de la noción de índice-, lo que es innegable es que la fotografía como práctica cultural plantea una relación problemática con los estados de cosas y acontecimientos que conforman el mundo.

De esta forma, gracias a este punto de apoyo, quisiéramos sugerir una primera distinción general entre dos tipos de imágenes fotográficas: la imagentransparente y la imagen-opaca. Ambas se distinguen en función de lo que

35 Aunque el libro fue publicado en 1990, los ensayos que contiene fueron escritos en su mayoría a lo largo de la década de 1970. 
hacen los signos que las conforman con la mirada ( $y$ con el pensamiento) del espectador. En el primer caso, los signos se ocultan y reenvían la mirada más allá de ellos, en dirección del referente representado. Esta imagen es "invisible" y nos da el mundo. La imagen-opaca, por su parte, retiene nuestra mirada y nos obliga a recorrer sus signos. Es una imagen "tangible" que nos da a ver algo distinto del objeto representado.

\section{§ 5. Esbozo de una primera clasificación de las imágenes fotográficas: la imagen-transparente y la imagen-opaca}

Como sostuvimos al inicio, la filosofía de Gilles Deleuze nos exhorta a realizar una consideración inmanente (materialista y pluralista) de las imágenes y dejar, gracias a ello, las aproximaciones idealistas que reducen la singularidad de las imágenes a categorías previamente establecidas. En este sentido, nuestro análisis debe partir de los componentes de la imagen. Por ello, siguiendo a Roland Barthes en "Retórica de la imagen", sostendremos que todas las imágenes ponen juego una multiplicidad heterogénea de signos: signos plásticos, icónicos y textuales ${ }^{36}$.

Ahora bien, ¿qué caracteriza al régimen de signos que da lugar a la imagentransparente? Esta se define, en primera instancia, porque organiza los signos que la conforman de tal modo que hace, por un lado, que olvidemos que estamos frente a signos -que están ahí en lugar de otra cosa, representándola-y, por otro lado, que olvidemos que lo que estamos observando es una imagen, es decir, un determinado tipo de objeto del mundo que, además de servir como representación de otros, tiene una realidad concreta y material en sí mismo.

Es debido a este doble olvido que este régimen de signos es "transparente". Aunque lo más preciso sería decir que es "invisible", pues la transparencia implica que existe algo reconocible que tiene dicha cualidad-como el vidrio de una ventana, por ejemplo-, pero en la imagen-transparente nos enfrentamos al ocultamiento radical de ese algo -la fotografía en tanto objeto-. Así, pues,

36 Cf. Barthes, Roland, "Retórica de la imagen”, en: Lo obvio y lo obtuso, Barcelona: Paidós, 2009, pp. 30-34. 
ante una imagen producida al interior de este régimen no vemos la imagen en tanto tal; vemos a través de ella, más allá de ella, fuera de ella.

De esta forma, en el régimen de la imagen-transparente, mientras mejor se oculta la materialidad y objetualidad de la fotografía, esta tiene más posibilidades de "darnos a ver". Pero, ¿qué es lo que nos da a ver? Simplemente la realidad: un estado de cosas en su pureza objetiva. Toda la fuerza de la imagen -su sentido y su valor- está puesto en el referente representado hacia el que redirige nuestra mirada y pensamiento, pues la función de dicha imagen es acercarnos a él.

Esta restitución se hace factible ya que los dispositivos fotográficos son capaces de sintetizar coherentemente, en la misma representación, los tres tipos de signos planteados por la semiótica de Pierce. De esta forma, la imagentransparente: I. es indicial, pues ha sido producida a partir de un contacto físico directo con el referente. Es, por tanto, una huella y se constituye como "prueba de existencia"; 2. Es, además, icónica, pues se asemeja al referente. Es, por tanto, un equivalente y se constituye como "fuente de inteligibilidad"; 3. Es, finalmente, simbólica, pues reconocemos el significado asociado convencionalmente (connotado) al objeto representado. Es, por tanto, significante y se constituye como "prueba de sentido".

Este régimen de signos implica consecuencias más allá de sí mismo. Desde una perspectiva ontológica, nos habla, en términos de Nietzsche, de un mundo "cualificado verídicamente": estable, idéntico, substancial y objetivo. Por otro lado, desde una perspectiva epistemológica, la imagen-transparente opera como fuente y vehículo de conocimiento: confirma la percepción natural logrando en ocasiones incluso ver lo que esta no puede. Es, por tanto, garantía de existencia y verdad.

Estéticamente hablando, las cualidades que componen estas imágenes reproducen con mayor fidelidad la percepción del sujeto en su relación con la presencia del objeto: punto de vista único, perspectiva tridimensional, profusión de detalles, foco en todos los planos, profundidad de campo, etcétera. La búsqueda de estas cualidades nos invitan a pensar en la supresión del sujeto creador, en, por tanto, la génesis automática de la imagen. Hay, así, una ética 
y una pedagogía en este régimen que consideran ilegitima por engañosa la manipulación ${ }^{37}$.

La imagen-transparente se construye, entonces, a partir de una ideología realista. En este sentido, la clásica noción de "mimesis", abandonada por la pintura a partir del nacimiento del impresionismo en la segunda mitad del siglo XIX-"coincidentemente" cuando nace la fotografía-, es quien domina la organización y función de los signos que componen este tipo de imágenes. El movimiento de desterritorialización de las fuerzas de la mimesis al abandonar la pintura halló su reterritorialización en la fotografía. La imagen-transparente opera entonces como un doble-del-mundo. Expresa la forma del pensamiento arborescente que Deleuze y Guattari pusieron en cuestión en Mil Mesetas. No activa procesos de pensamiento que nos empujen a ver lo invisible y a pensar lo impensable. Son, como dice Didi-Huberman, imágenes tautológicas: parecen decirnos "lo que ves es lo que es"38.

Sin embargo, en virtud de su carácter "neutral" en relación a la génesis del pensamiento, son muy adecuadas para realizar diversas "funciones sociales": informar, conocer, describir, controlar, archivar, registrar, comunicar, etcétera. De hecho, fue al realizar estas estas tareas eficientemente que este régimen de la imagen alcanzó un lugar preponderante en la nueva cultura burguesa y positivista del siglo XIX. Por otro lado, la fuerza de la fotografía "documental" y del "fotoperiodismo" a lo largo del siglo $X X$ surge también del carácter transparente de este tipo de imágenes.

Esto se puede confirmar si observamos con detenimiento cómo se vincula la definición, características y usos que le hemos atribuido a la imagentransparente con los postulados que, según Deleuze, sostienen a la imagen dogmática del pensamiento, es decir, metafísica. Estos postulados aparecen en la obra de Deleuze en diferentes momentos, como en Proust y los signos ${ }^{39}$ y en Nietzsche y la filosofía $a^{40}$, sin embargo, es en Diferencia y repetición donde

37 Cf. Rouillé, André, La photographie. Entre document et art contemporain, París: Gallimard, 2005, pp. 102-119.

38 Cf. Didi-Huberman, Georges, Lo que vemos lo que nos mira, Buenos Aires: manantial, 1997, pp. $19-26$.

39 Cf. Deleuze, Gilles, Proust y los signos, Barcelona: Amorrortu, 1995, pp. 12-36.

40 Cf. Deleuze, Gilles, Nietzsche y la filosofía, pp. 146-156. 
se presentan mejor desarrollados. El pensamiento dogmático -aquel que se fundamenta en la noción de Identidad- se sostiene, afirma Deleuze, en ocho postulados $^{41}$ : I. Buena voluntad y recta naturaleza del pensamiento; 2 . Buen sentido y sentido común; 3. Función del reconocimiento; 4. Elemento de la representación; 5. El error como negativo del pensamiento; 6. La proposición como lugar de la verdad; 7 . Soluciones; 8 . Saber.

El régimen de la imagen-transparente coincide con estos postulados: en primer lugar, presuponemos una buena voluntad y una recta naturaleza, tanto del productor de la imagen como de los receptores, esto quiere decir que ambos ven en la fotografía un vehículo honesto y capaz de transmitirnos determinados contenidos del mundo; en segundo lugar, asumimos que lo que observamos en una fotografía (presente) es lo mismo que sucedió en el momento de la captura (pasado), así percepción, memoria y entendimiento colaboran para la construcción de un sentido común; en tercer lugar, es clave aquí también la función del reconocimiento: lo que estas imágenes nos exigen/ invitan es a reconocer los signos que expresan, mientras más claramente lo hagamos, mejor; por ello, en cuarto lugar, las imágenes-transparentes son eminentemente representativas (figurativas), encierran lo observado en las formas de la semejanza y la identidad; en quinto lugar, el error solo se concibe acá como la interferencia de algún factor externo: manipulación de la imagen, utilización equivocada, etcétera, pero nunca como una potencia de lo falso inherente a la propia imagen; por ello, en sexto lugar, el significado de una imagen-transparente surge de su capacidad de corresponder al estado de cosas supuestamente representado; así, en séptimo lugar, todo imagen de esta naturaleza más que presentarse como un problema, más que abrir el mundo, es una forma de cerrarlo, de ofrecernos una solución; finalmente, las imágenes-transparentes apuntan a ofrecernos cada vez más conocimientos positivos acerca del mundo.

Según lo dicho, el régimen visual de la imagen-transparente se construye como una forma de perpetuar las categorías fundamentales de lo que Deleuze califica como "la imagen dogmática del pensamiento". En ese sentido, se podría sostener, como hipótesis provisional, que la fotografía surge en el siglo XIX 
como un nuevo refugio, de corte técnico-industrial, para el espíritu metafísico occidental que, como afirma Nietzsche, va cambiándose de máscara a lo largo de la historia para poder sobrevivir (pasó de la filosofía idealista a la religión monoteísta, luego a la ciencia racionalista para aterrizar finalmente en la imagen técnica).

¿Qué implica, por su parte, el régimen visual de la imagen-opaca? Al presenciar una imagen-opaca se hace patentealgo indeterminado que detiene nuestra mirada y no le permite pasar a través de la imagen en busca del objeto fotografiado en el mundo exterior. De esta forma, una imagen de esta naturaleza no se construye a partir de una organización coherente, es decir, normalizada, de signos que significan y refieren de forma clara y distinta al referente que supuestamente representan.

Frente a este tipo de imágenes el espectador puede adoptar dos posiciones: o dejarla ir, incapaz de hallar en ella algo que convoque a su pensamiento; o, por el contrario, puede afectarse por la presencia de esa "inquietante extrañeza", en palaras de Freud, que nos empuja, como enfrentados a un enigma, a descifrar sus secretos. La imagen-opaca se resiste ante nosotros, se pliega ante nuestra mirada, por ello aparece siempre como problema y nos reenvía la siguiente pregunta: ¿qué vemos en lo que vemos?

Este bloqueo ante las imágenes opacas nos muestra que estas no son otra cosa que un determinado tipo de objeto material que ocupa un lugar en el mundo. No se oculta a sí misma y, por tanto, no oculta tampoco los signos que la componen (líneas, volúmenes, formas, texturas, colores, tonos, luces, sombras, textos, etcétera). Se revela ya no como una "ventana" totalmente transparente que permite ver sin dificultad lo que está más allá de sí misma, sino como un "pantano" habitado por extrañas figuras. No hay, pues, invisibilidad. Esta manifestación abierta de su propia materialidad permite que la imagen-opaca nos dé a ver al tiempo que nos impide ver. La relación se invierte: ahora lo que se nos niega, o arrebata, es el mundo representado, pero en ese mismo movimiento se nos dan a ver otros mundos. Aquí radica la paradoja de la imagen-opaca: en tanto nos detiene en su propia materialidad significante, parece ser la menos adecuada para mostrarnos algo más allá de sí misma. Pero resulta que justamente el obligarnos a considerarla como una síntesis de signos heterogéneos implica que es susceptible de dar lugar a 
múltiples procesos de significación y, por tanto, a múltiples lecturas que, en vez de aquietar al pensamiento al decirle "lo que ves es lo que es", lo activan al mostrarle un mundo devenido problema, signo de interrogación.

Es aquí donde radica la máxima potencia de la imagen-opaca. Inútil desde el punto de vista del conocimiento y la acción, la imagen-opaca se revela absolutamente potente para activar procesos de pensamiento en el espectador. La imposibilidad de atravesar la imagen para detenernos plácidamente luego de la identificación del referente, hace que el espectador devenga vidente-como dice Deleuze en relación a la crisis de la imagen-acción en los estudios sobre cine-. La videncia implica ver lo invisible, leer lo ilegible y pensar lo impensable desde el punto de vista de la representación. La imagen-opaca lleva nuestra subjetividad a ese límite último en el que no tiene opción y debe presenciar, contra su voluntad, la génesis de su propio pensamiento.

A partir de este primer esbozo podemos sacar dos conclusiones útiles para desarrollar posteriores investigaciones. Por un lado, vemos que es necesario desplegar una clasificación precisa de imágenes al interior de cada una de estas grandes categorías (imagen-transparente e imagen-opaca) para establecer las múltiples formas de representación fotográfica que se han propuesto a lo largo de los casi 200 años de historia del medio. Asimismo, podemos concluir que, a partir de los rasgos que se le atribuyen a la imagen-opaca, sí es posible ver en la fotografía una realidad capaz de, como pedía Deleuze siguiendo a Heidegger, dar a pensar -y esto a pesar de la comprensión que tuvo Deleuze de la imagen fotográfica, reducida para él a imagen-transparente y, por tanto, metafísica. 